\title{
A Preliminary analysis: digital inclusion domain in Islamic Education
}

\author{
Unik Hanifah Salsabila ${ }^{\text {a,1,**}}$ \\ ${ }^{a}$ Ahmad Dahlan University, Yogyakarta, Indonesia \\ ${ }^{1}$ unik.salsabila@pai.uad.ac.id* \\ * corresponding author \\ Unik Hanifah Salsabila
}

\section{ARTICLE INFO}

Article history

Received 2019-05-14

Revised 2019-05-29

Accepted 2019-05-31

Keywords

Domain

Teknologi Digital

Pendidikan Agama Islam

Analisis

Identifikasi

\section{ABSTRACT}

One of the environmental changes that have successfully influenced the world of education universally is the pace of digital technology. In the context of education, the emergence of the concept of developing modern technology based on Internet of Things (IoT) and distance learning, certainly demands the optimization of technological utilization. Islamic Education is a catalyst for cross-generation spiritual literacy developers who should not be ignorant of any changes that occur. Responding to the increasingly unpredictable rate of digital technology, an attitude of awareness needs to be done, one of which is through mainstreaming digital inclusion in learning so that the advancement of digital technology can be restored to its role as a medium to increase the effectiveness of knowledge not as a barrier to the learning process. This study tries to identify several domains from digital inclusion into Islamic Education for higher education through a literature review. Some of the digital inclusion domains detected in this study are social networking, entertainment applications, information search engines, websites, and e-learning. This research is a preliminary analysis of the utilization and involvement of digital technology in the learning of Islamic Education and has produced several information regarding the identification of several digital inclusion domains, accompanied by strategies and techniques of implementation in learning activities. The study also includes academic advice for future studies.

This is an open access article under the CC-BY-SA license.

\section{Introduction}

The pace of digital technology, especially the internet, with all its development features, has had a significant impact on people's lives in various aspects, including education, social relations, economics, entertainment, and communication patterns. This reality confronts the world of contemporary problem education as stated by Prensky, that one of the many essential problems experienced by the current education system is, the fact of educators or instructors originating from the digital generation of immigrants and the reality of students from the digital generation native [1]. These problems arise because of the fundamental differences in the aspects of the utilization of digital technology in every life activity, if the digital immigrant generation places digital technology as the second source of information and tends to emphasize textbooks as the primary source of information, on the contrary, digitally native generation puts digital technology and all digitalization its development as the primary source of information for every aspect of life. This phenomenon shows the existence of a cross-generation digital divide that allows for potential misunderstandings in the learning process. 
For example, later most educators or instructors tend to assume that $21^{\text {st }}$ century students are generations with strong character and personality so that it is difficult to be educated by using media and learning content that has always been practiced for the previous decades, while students assume that educators or instructors teach content that is less applicable so it cannot keep up with the times and seems old-fashioned and boring [2]. Students who are currently in college are the first generation of the 21 st century to grow with the concept of the 4th platform technology, where almost all of their lives are surrounded by various kinds of modern digital equipment, such as computers, video games, digital music players, digital cameras, smartphones, as well as the hustle and bustle of various types of social media platforms originating from the digital era. So it can be calculated, the numerical comparison between the time spent reading textbooks by playing in a digital area by the students is in the range of $5000: 10000$ hours of their entire lives [1].

Changes in the conditions of such times have led students to the process of receiving information and thought processing that is fundamentally different, compared to the generations that preceded it. As Bruce said from Baylor College of Medicine, that various types of modern and advanced experiences had changed the formation of brain structures that can produce thoughts and acceptance of specific information within a person [1]. These underlying conditions result in differences in the formation of brain structures across generations, so it is not surprising that the conclusions produced will also tend to be different. In the context of learning Islamic Education, the causative learning content that tends to be absolute and normative in Islamic Education will feel saturating if the learning pattern is only made in one direction, that is, without being confused with the synergy between students and lecturers. Responding to this reality, of course in the future the system of implementing Islamic education needs to review the domain of the utilization and involvement of digital technology in the learning process, so that synergy can be established that can increase the effectiveness of learning in the classroom.

Some Islamic education system organizers have tried to find a middle ground to overcome the digital divide by making digital technology a learning outcome as well as a media for content integration, but not a few Islamic education systems that seem to be closed and neglecting the pace of digital technology in the era this time. Some of the cases caused by ignorance of the digital divide across generations are the emergence of the legitimacy of digital technology as a factor in the rise of secular attitudes, moral decline, psychological malaise, ecological destruction, and so on. Even recently there was a corner of mutual attitude towards specific individuals who had an intense closeness with digital technology in the learning process. These assumptions are getting stronger with the emergence of various kinds of relevant research, such as a study that states that some $73 \%$ of internet users have witnessed someone being harassed online and some $40 \%$ of internet users have ever experienced such abuse [3].

These conditions increasingly indicate that the digital divide that is not bridged selectively can sharpen differences in good thinking across generations, both in cyberspace and in the real world. Responding to these urgent needs, it is assumed that the fundamental knowledge related to the use of digital technology positively in the classroom can erode the digital divide across generations, especially in the learning of Islamic Education, as revealed by Mahedy that the emergence of digital technology should be used to improve the quality of Human Resources (HR) so that it also automatically influences the quality of education itself [4]. The conception is also a concrete manifestation of the mandate of Indonesian legislation, to educate the nation while providing positive services to the public, especially in the telecommunications and information fields. Various studies on the need for digital technology involvement in various aspects of life, such as economics, business and so on, have been widely discussed by researchers before, but no research has attempted to identify the domain of digital inclusiveness and its utilization techniques in the learning process Islam.

\section{Discourse on Digital Inclusion}

Some experts interpret digital inclusion as a real manifestation of optimizing the use of the internet for various purposes in a fast and smart way [5]. The indicators of digital inclusion consist of access, skills, and also motivation for digital involvement in particular content so that later it will lead to tangible results in various fields, both economic, social, cultural, educational, and personal life [6]. The first review to be able to distinguish correctly, between the digital divide and digital inclusion in the aspect of education is through the element of accessibility, only then is further review carried out on the components of knowledge and also the skills of using the internet for more complex policies. 
The more evenly distributed accessibility capabilities of digital technology in academic society, the community is categorized as increasing inclusion. Therefore correctly, digital inclusion can be interpreted as the ability of individuals and communities to be able to access and use information, communication, and also technology [6].

The ease of access provided by digital technology will provide equal opportunities for every member of the community, to obtain the benefits offered by the technology so that in turn the utilization of digital technology will also lead to the process of empowering society at large. While the ability to innovate in the use of digital technology in a particular aspect will have an impact on the welfare of other aspects of life which are also involved in their interactions. In this context, various types of research have mentioned the existence of a relationship between utilization and innovation of digital technology with motivation to improve achievement in the learning process [7]. As if based on the context of diversity, digital inclusion is also interpreted as a space for digital involvement in an aspect of life to promote differences, practice respect, and support universal access to every member of society [8].

This conception presents digital inclusion in the toughest challenges in the form of the ability to utilize digital literacy, the reality of low financial literacy, and the disparity in the delivery of information and digital technology infrastructure, especially for 3T (Disadvantaged, Outermost, Inner) regions that tend to experience shortages in terms of access to formal financial distribution . In response to these conditions, the application of an optimal digital inclusion concept can lead to the fulfillment of the promise of the existence of digital technology, namely to accommodate diversity, experience, and insight for everyone whenever and wherever they are [8]. Later, digital inclusion and online services became a contemporary issue in various aspects of life due to the decline in offline service populations. In various aspects of life, digital inclusion is proven to be able to bring people to a more advanced condition, including in the fields of communication, productivity, economics, information seeking, skills, insight development, empowerment of women and youth, and various levels of participation, both within the company and in the general public environment [9]. Whereas in the field of education, digital inclusion is seen as a solution to solve problems around increasing the participation and motivation of learning for each.

However, in reality, these achievements are not necessarily appropriately realized, especially to answer the challenges of innovation in learning Islamic Education. There are still many institutions that administer Islamic education that define the modernization of digital technology merely in the realm of ideology which is written textually and has not been realized in the contextual applicative domain. For example, the introduction of the use of digital technology only as a means of online communication, entertainment, and other private use areas is not a medium for delivering effective and efficient learning content in the classroom. Based on these problems, the indicator elements of digital inclusion also need to be expanded through the development of new instruments that can identify clarity regarding the extent of digital inclusion domain involvement in more specific learning activities. In this regard, several researchers have developed measurements of digital skills through the identification of several different dimensions, such as operational skills, information acquisition, social relations, the use of cellular media, and creativity. Subsequent studies have also tried to identify the forming elements of digital inclusion attitudes, such as the internet as a medium of information, communication patterns, and the availability of digital-based services [10]. However, all of these studies are in the non-educational area so that it is considered necessary by the authors to begin to identify new dimensions of digital inclusion domains in the field of education.

\section{Digital Inclusion Domain}

Based on the literature review that has been done, the digital inclusion domain based on the techniques of its utilization in the field of Islamic Education can be categorized as follows:

\subsection{Social Networking}

Social networking is identified as a medium for delivering information, actual learning resources, and instant messaging media. Steve Wheeler, in his article entitled Digital Literacies for Engagement in Emerging Online Cultures, states that there are nine essential elements in the concept of digital inclusion, which include social networking, transliteracy, maintaining privacy, managing digital identity, creating content, organizing and organizing content sharing, reusing or repurposing content, 
filtering and selecting material, and self broadcasting [11]. Based on the elements contained in these nine elements, it is assumed that the ability to search, utilize, evaluate, and understand the content of free circulating social networks among students is so relevant, and in this context the academic space becomes the starting point for the birth of digital literacy among the native digital generation.

A study states that there are $88.24 \%$ of tertiary education graduates holding bachelor and master's degrees, a category of people whose lives are always connected to the internet, especially social networks. While for Bachelor and Diploma graduates there are several 79.23\% [12]. This reality shows how the existence of optimally optimized social networks can lead to the effectiveness of academic achievement towards an increasingly high level. Some of the techniques for using digital inclusion through social networking platforms are as follows:

\subsubsection{Paperless Task Collection}

Through various types of social networking, lecturers of Islamic Education can begin to socialize paperless distance collection methods. For example, they are collecting evidence of the implementation of a project using hashtag photo media on Instagram or Twitter, or a competition for making original vlog recordings on Youtube that are based on the number of subscribers, etc.

\subsubsection{Presentation of Actua Learning Information}

The availability of various types of actual phenomena that occur in the broader public environment and are linked by social networking virtual traces can be used as relevant case studies for certain learning theme content in Islamic Education. For example, giving examples of qoulan sadiida in the Qur'an and verbal abuse actions caused by ignoring the concept said well, through netizens' comments found on many social networks. Lecturers can also relate the theme of religious, spiritual nuances about kind words with the Electronic Information and Transaction Law (ITE) which is rife in the virtual universe [13] so that learning content becomes actual and more attractive to students.

\subsubsection{Development of Thematic Insight}

Social networking is a public space that can be used to voice various kinds of ideas, criticisms, and suggestions in various fields of life openly without being limited by space and time. In this context, it would be typical for social networks to be used by lecturers to assist students directly in terms of credible and accountable ways to find information, especially for information that examines normative issues in Islamic Education. For example, optimizing the use of specific hashtags on social networks to search for information, identify confusing information on social networks and then analyze the solution from a religious, academic point of view, etc.

\subsubsection{Media Data Collector}

In an increasingly modern and busy era like today, it is difficult for a researcher to be able to gather several targeted masses that are relevant to learning and research needs so that a collection of valid and reliable data is obtained. Responding to the reality of these limitations, advances in digital technology provide space for the process of collecting data across time and space through social networks. For example, taking survey data through Google Form, which attempts to spread its virtual questionnaire is done by optimizing various types of social networking platforms. In addition to the specific data collection, the implementation of the virtual questionnaire also indirectly affects the promotion aspects of the institution in question as well as specific learning content. If so far people tend to recognize the learning content of Islamic Education as a collection of stagnant and saturating insights, then through the innovation of utilizing social networks, students and non-educational communities can see the affective side of content in learning Islamic Education. This strategy is increasingly empowered by several young present-day officials who intensely promote their knowledge through social networks so that the process of delivering their spiritual advice becomes more exciting and rhetorical among teenagers. Rhetorical or speech analysis and ideological approaches are the main attraction for the native digital generation so that the content delivered will be easy to remember and disseminate. The technique indeed leads to the speed of social change that allows for a broader and more sustainable scope of communication in the context of public mobilization [14]. 


\subsection{Entertainment Application}

The pace of digital technology strongly supports the availability of entertainment facilities in the form of instant applications that can be accessed quickly and openly [15]. Students and instructors can access the majority of the availability of these programs for free. Psychologically, entertainment is an activity that is divergent or allows someone to be able to entertain themselves in their spare time in the desired way [16]. Through the pace of digital technology, entertainment applications become virtual goods that can be accessed whenever and wherever they are. A survey conducted on several internet users related to the utilization of online entertainment in Germany in 2013 showed that there were around 3.66 million Germans aged 14 years and over who used virtual entertainment applications at least once a day to entertain themselves [17]. The individual psychological potential should be used by lecturers to create an entertaining but meaningful learning context and is easily accessible to students. For example, learning Arabic using the Quizizz, Kahoot, and so on game applications. Through these entertainment applications, lecturers can also quickly assess students in an exciting way.

\subsection{Information Search Engine}

Learning information search certainly requires credible sources to be used as references. The existence of information search engines in digital form makes it easier for lecturers and students to access various types of information in the shortest possible time with the acquisition of results as complete and as possible. The ability to measure the credibility of available information sources is a part of digital literacy that must be developed by lecturers in the classroom. The presentation of feedback on the use of digital technology as a reference seeker will enable the occurrence of a digital inclusion synergy, where students gain the freedom to optimize themselves according to their computational talents, and lecturers gain space to pass on their self-awareness of the openness of existing access.

\subsection{Website}

In education, a website is defined as a website design that is used to communicate certain academic information. A light and informative website will provide comfort in completing administrative matters. For example, the development of a website for the portal of taking courses, lecturer evaluations, to a comprehensive online campus survey in the scope of the education unit. Through the website, students also practice developing their independence towards every available academic instruction. Later, the site was also used as a location for laying out a virtual administrative form that became a complete executive student as well as a media for conducting seminars and virtual lectures conducted across countries and islands.

\subsection{E-Learning}

Jaya Kumar defines e-learning as the use of electronic circuits (LAN, WAN, or internet) in the teaching and learning process as a catalyst media for delivering content, interactions, and guidance [18]. Whereas Dong defines e-learning as asynchronous learning activities carried out through a set of digital technologies that have been adapted to learning needs [19]. Based on these definitions, the utilization of e-learning in the context of Islamic Education can be empowered for a variety of functions and techniques, including academic media announcements, media for delivering learning materials, and administrative media for online presence.

\section{Conclusion}

Identification of digital technology domains that are relevant to the learning of Islamic Education requires structured guidance, both from higher education institutions and lecturers, thus leading to the conception of digital inclusion development. The hope is that the gradual development of digital inclusion can erode the digital divide across generations, and in turn will shift to the synergy of crossgeneration digital literacy that enables an increase in welfare in various aspects of the interaction involved. Full digital inclusion is assumed to be a solution to reduce cross-generation misunderstandings, where each generation of both digital immigrants and digital natives can express the accent innate in their times without intervening with each other. The set of attitudes, understandings, and skills in accessing, managing, and conveying information indirectly is also a socialization of the awareness of positive internet use, for example prevention of the spread of hoax news and increasing habituation in the community to conduct academic filters on any information obtained so that various types of critical and responsible academic evaluations. Analysis of 
identification of digital technology domains is intended to be a trigger for the utilization of digital technology more specifically in learning Islamic Education at the college level. Thus, normative material which is a distinctive identity of Islamic Education is not merely a formal content that is taught repeatedly to students in the classroom but becomes a religious solution for every contextual life problem. After this study succeeded in identifying several digital inclusion domains in the field of Islamic Education through a review of literature, further research can develop further investigations regarding the addition of relevant domains using more applicable empirical research to review the extent of the practice of utilizing these domains.

\section{Acknowledgment}

This research was supported by the Islamic Religion Education Study Program at the Faculty of Islamic Studies at Ahmad Dahlan University, Yogyakarta. The author expresses his gratitude to all fellow lecturers, and students in the Islamic Education Policy and Neuroscience course who have been the inspiration in this writing.

\section{References}

[1] M. Prensky, "Digital Natives, Digital Immigrants Part 1," On the Horizon, Vol. 9, No. 5, pp. 16, Sep. 2001.

[2] D. Tauhidi, "The Tarbiyah Project," Towards A Renewed Vision of Islamic Education, p. 8, 2001.

[3] M. Duggan, "Online Harassment," Pew Research Center, 2014. [Online]. Available: https://www.pewinternet.org/2014/10/22/online-harassment/. [Accessed: 12-May-2019].

[4] K. S. Mahedy, "Peranan Teknologi Informasi dalam Meningkatkan Kualitas Pendidikan," Jurnal Pendidikan Teknologi dan Kejuruan, Vol. 6, No. 2, Aug. 2017.

[5] J. R. Situmorang, "Pemanfaatan Internet sebagai New Media dalam Bidang Politik, Bisnis, Pendidikan dan Sosial Budaya," Jurnal Administrasi Bisnis, Vol. 8, No. 1, pp. 73-87, 2012.

[6] S. M. H. S. Khairuddin, F. I. Omar, and N. Ahmad, "Digital Inclusion Domain in Entrepreneurship: A Preliminary Analysis," Advanced Science Letters, Vol. 24, No. 4, pp. 27212724, 2018.

[7] Y. A. Sarbani and P. S. Subandoro, "Memahami Motivasi Berprestasi dan Manfaat Penggunaan Gawai Bagi Generasi Digital Native," British Journal of Psychiatry, Vol. 205, No. 01, pp. 7677, Mar. 2014.

[8] "Tantangan Inklusi Digital Bagi Perempuan | Indonesia Baik." [Online]. Available: http://indonesiabaik.id/infografis/tantangan-inklusi-digital-bagi-perempuan. [Accessed: 13May-2019].

[9] H. J. Seo, Y. S. Lee, J. J. Hur, and J. K. Kim, "The Impact of Information and Communication Technology on Skilled Labor and Organization Types," Information Systems Frontiers, Vol. 14, No. 2, pp. 445-455, Apr. 2012.

[10] F. I. Omar, S. A. Rahim, and A. Salman, "Penyertaan Digital dan Ciri Keusahawanan dalam Pemeriksaan Usahawan Wanita di Malaysia," Malaysian Journal of Communication, Vol. 31, No. 1, pp. 241-256, 2015.

[11] S. Wheeler, "Digital Literacies for Engagement in Emerging Online Cultures," eLC Research Paper Series, Vol. 5, No. 5, pp. 14-25, 2013.

[12] U. Wahidin, Edukasi Islami: Jurnal Pendidikan Islam., Vol. 7, No. 02. Al Hidayah Press, 2018.

[13] UU No. 20 Tahun 2008, “Undang-Undang Republik Indonesia," UU No. 20 Tahun 2008, No. 1, pp. 1-31, 2008.

[14] A. F. B. dan V. E. Meidasari, "Trendsetter Komunikasi di Era Digital: Tantangan dan Peluang Pendidikan Komunikasi dan Penyiaran Islam," Jurnal Komunikasi Islam, Vol. 4, No. 1, Jun. 2014.

[15] Deloitte, "Digital Media: Rise of On-demand Content," 2018.

[16] I. J. Mann, “<Impact of Internet on Customer Loyalty.pdf>," p. 100.

[17] "Frequency of internet use in Germany 2018 | Statistic." [Online]. Available: 
https://www.statista.com/statistics/379036/internet-usage-at-home-germany/. [Accessed: 14May-2019].

[18] C. K. Jaya Kumar, "Dalam Pengajaran dan Pembelajaran di sekolah-Sekolah Malaysia," Elearning, Vol. 3, p. 13, 2001.

[19] H. Kamarga, Alternatif Belajar Sejarah Melalui e-Learning: Mengakses Sumber Informasi Kesejarahan, Cet. 1. Jakarta-Bandung: Intimedia, Pustaka Nusantara, 2002. 